\title{
Effects of Progestogen Oral Contraception with Norethisterone on Blood Clotting and Platelets
}

\section{Introduction}

Oestrogen-progestogen oral contraceptives produce acceleration of blood clotting (Thomson and Poller, 1965; Poller et al., 1968) and increased platelet aggregation (Poller et al., 1969). Changes in clotting have not been detected, however, with a 17-acetoxysteroid progestogen, chlormadinone acetate, when used as a progestogen-only oral contraceptive. Platelet changes were delayed and less severe than with combined preparations (Poller et al., 1971a).

Since 1969, when chlormadinone acetate was withdrawn from sale for reasons unconnected with thrombosis, only combined preparations have been marketed. Recently the 19-norsteroid progestogen, norethisterone, became available for clinical trial. There is evidence that 19-norsteroids may be broken down into oestrogen in the body (Brown and Blair, 1960) and thus might resemble combined preparations in producing undesirable effects on blood clotting.

A study has therefore been conducted on the effects of the continuous daily administration of $0.35 \mathrm{mg}$ norethisterone in a group of 63 women volunteers followed for a period of six monthly cycles.

\section{Subjects and Method}

Laboratory studies were performed before starting and at intervals of one, two, three, and six months. The women in the

\footnotetext{
Haematology Department, University Hospital of South Manchester, Withington Hospital, Manchester

L. POLLER, M.D., M.R.C.PATH., Consultant Haematologist

JEAN M. THOMSON, F.I.M.L.T., Chief Research Technician

P. W. THOMAS, A.I.M.L.T., Technician
}

study were divided into four groups for statistical analysis, each group being analysed separately. With one exception all the women were included in a parallel clinical follow-up, details of which will be reported elsewhere (Burslem et al., 1972). The study group were as follows.

Group 1.-Sixteen women who were taking an oral contraceptive for the first time.

Group 2.-Twenty-eight women who had been taking combined oestrogen-progestogen oral contraceptives for an average of 33 months before inclusion in this study. Two women had intervals of up to two months before starting norethisterone, the remainder changed at the end of their current cycle of combined oral contraception.

Group 3.-Thirteen women who had previously been taking the progestogen-only oral contraceptive chlormadinone acetate for at least two years.

Group 4.-Six women who were between the second and fifth month postpartum at the time of the base line studies.

The following tests were performed at each visit by using the techniques described previously (Poller et al., 1971b): prothrombin time, kaolin-activated cephalin time, factors VII and X assays, thrombelastography (reaction time, thrombin time, and maximum amplitude values), platelet aggregation time (Chandler's tube technique), fibrinogen assay, and haemoglobin and platelet count. The method for factor VII assay was modified from previous reports by the use of congenital factor-VII deficient substrate plasma obtained from beagle dogs instead of coumarin factor-VII deficient plasma (Poller et al., 1971c). The platelet adhesiveness test, using the technique of Hirsh and McBride (1965), was performed in $43 \%$ of the 265 investigations. The limiting factor was the extra volume of blood required from the women volunteers. Fibrin/fibrinogen breakdown products were measured by two different techniques: the haemagglutination inhibition assay (Merskey et al., 1969) using human group $O$ cells, and the staphylococcal clumping test (Leavelle et al., 1971). Fibrin/fibrinogen breakdown products were measured before starting, and repeated at the three-month and six-month stages. Antithrombin III measurements (Abildgaard et al., 1970) were performed before the start of norethisterone and again after six months.

Results were analysed against the base line readings of the individual group by using the paired $t$ test in all four series.

\section{Results}

The women attended on 265 occasions out of a possible maximum of 315 visits.

Group 1.-This group who had not previously taken oral contraceptives showed no coagulation changes during six months' norethisterone administration (Table I). There was

TABLE I-Results of Coagulation Studies up to Six Months in 16 Women Taking Oral Contraceptives for the First Time. Numbers of Women are given in Parentheses

\begin{tabular}{|c|c|c|c|c|c|c|c|}
\hline & & $\begin{array}{c}\text { Prothombin } \\
\text { Time (sec) } \\
(\mathrm{n}=16)\end{array}$ & $\begin{array}{c}\text { Cephalin Time } \\
(\mathrm{sec}) \\
(\mathrm{n}=16)\end{array}$ & $\begin{array}{l}\text { Factor VII } \\
\text { Assay (sec) } \\
(\mathrm{n}=16)\end{array}$ & $\begin{array}{c}\text { Factor X } \\
\text { Assay (sec) } \\
(\mathrm{n}=16)\end{array}$ & $\begin{array}{c}\text { Fibrinogen } \\
(\mathrm{mg} / 100 \mathrm{ml}) \\
(\mathrm{n}=16)\end{array}$ & $\begin{array}{c}\text { Platelet Aggregation } \\
\text { Time (min) } \\
(\mathbf{n}=15)\end{array}$ \\
\hline $\begin{array}{l}\text { Before starting } \\
1 \text { month } \\
2 \text { months } \\
3 \text { months } \\
6 \text { months }\end{array}$ & $\begin{array}{l}\text { Mean } \\
\text { Mean } \\
\mathbf{P} \\
\text { Mean } \\
\mathbf{P} \\
\text { Mean } \\
\mathbf{P} \\
\text { Mean } \\
\mathbf{P}\end{array}$ & $\begin{array}{c}12 \cdot 2 \\
12 \cdot 4 \\
0.3 \\
12 \cdot 4 \\
0.5-0.4 \\
12 \cdot 6 \\
0.05-0.02 \\
12 \cdot 4 \\
0.3-0.2\end{array}$ & $\begin{array}{c}41.4 \\
41.5 \\
0.7-0.8 \\
40.9 \\
0.9-0.8 \\
40.6 \\
0.2-0.1 \\
40.3 \\
0.4-0.3\end{array}$ & $\begin{array}{c}12 \cdot 4 \\
12 \cdot 5 \\
0.7-0.6 \\
12 \cdot 3 \\
0.3-0.2 \\
12 \cdot 8 \\
0.2-0.1 \\
12 \cdot 7 \\
0.3-0.2\end{array}$ & $\begin{array}{c}20.8 \\
20.9 \\
21.5 \\
0.3 \\
22 \cdot 1 \\
0.3-0.2 \\
22.7 \\
0.05-0.02\end{array}$ & $\begin{array}{c}247 \\
245 \\
>0.9 \\
248 \\
0.6-0.5 \\
231 \\
0.3-0.2 \\
233 \\
0.3-0.2\end{array}$ & $\begin{array}{c}523 \\
506 \\
0.9-0.8 \\
557 \\
0.3-0.2 \\
607 \\
0.01-0.001 \\
583 \\
0.2-0.1\end{array}$ \\
\hline
\end{tabular}


in contrast a tendency to prolongation of the factor $\mathrm{X}$ assay, which became statistically significant at six months. The reaction time, measured by the thrombelastograph thought to correspond to the early stage of "intrinsic" coagulation, was also prolonged, becoming significantly lengthened at the threemonth stage. The platelet adhesion test showed no change over the six-month period. On the other hand the Chandler's tube platelet aggregation test became prolonged at three months. Fibrinogen, fibrin/fibrinogen degradation products, antithrombin III levels, haemoglobin and platelet counts remained unchanged.

Group 2.-The group of 28 women who changed from combined preparations to the progestogen-only oral contraception with norethisterone showed quite pronounced changes (Table II, Chart). Prothrombin times, factor VII and X assays,

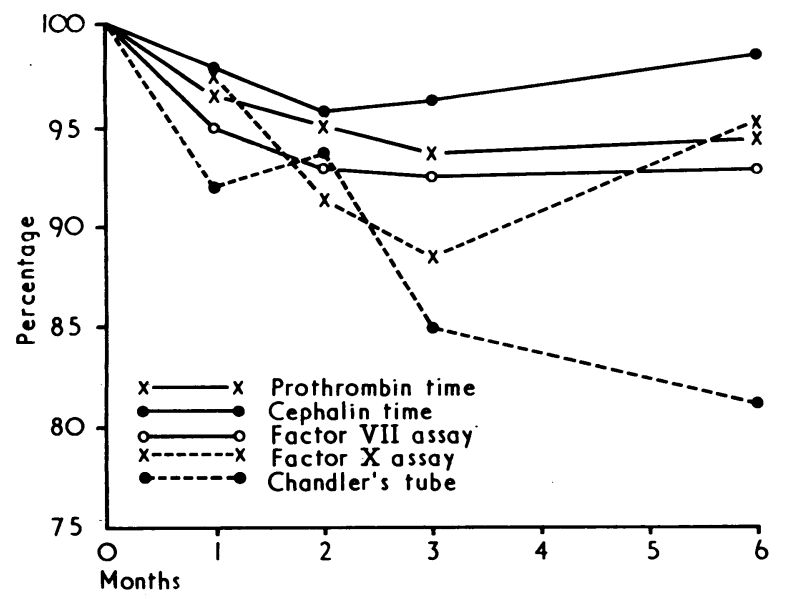

Clotting times of patients on combined preparations represented as percentage of clotting time after changeover to norethisterone, showing fall in clotting activities. and cephalin times and platelet aggregation times became significantly prolonged between one and three months. Fibrinogen levels became lower than when on combined preparations at one to two months, and a tendency to reduced coagulability was also seen in the thrombelastogram. There was no significant change in fibrin/fibrinogen breakdown products, antithrombin III levels, haemoglobin levels, and platelet counts.

Group 3.-The 13 women who changed from progestogenonly oral contraception with the 17 -acetoxysteroid preparation chlormadinone acetate to the 19-norsteroid norethisterone showed no change in clotting or platelet tests or other criteria over the first six months (Table III).

Group 4.-The postpartum group who were started on norethisterone were analysed separately because of possible postpartum hypercoagulability. There was no evidence of clotting or platelet changes in these six women (Table IV).

\section{Discussion}

Two main findings emerge from this study of progestogen-only oral contraception with the 19-norseroid norethisterone. No acceleration of clotting or platelet function was detected in women who had not previously taken an oral contraceptive, but a tendency to reduced coagulability was observed during the first six months of norethisterone administration. The second important observation was that there was a significant prolongation of most of the tests in women who had been receiving oestrogen-progestogen oral contraception during the first three months after stopping combined preparations.

These findings are substantially the same as those reported during the first months of progestogen-only oral contraception with the 17-acetoxysteroid chlormadinone acetate (Poller et al., 1969) and are reassuring in view of the evidence that 19-norsteroids may be broken down into oestrogen in the body (Brown and

TABLE II-Results of Coagulation Studies up to Six Months in 28 Women who Changed from Combined Preparations to Norethisterone. Numbers of Women are given in Parentheses

\begin{tabular}{|c|c|c|c|c|c|c|c|}
\hline & & $\begin{array}{c}\text { Prothrombin } \\
\text { Time (sec) } \\
(\mathbf{n}=\mathbf{2 8})\end{array}$ & $\begin{array}{c}\text { Cephalin Time } \\
(\mathrm{sec}) \\
(n=28)\end{array}$ & $\begin{array}{l}\text { Factor VII } \\
\text { Assay (sec) } \\
(\mathbf{n}=\mathbf{2 8 )}\end{array}$ & $\begin{array}{c}\text { Factor X } \\
\text { Assay (sec) } \\
(\mathbf{n}=\mathbf{2 8})\end{array}$ & $\begin{array}{c}\text { Fibrinogen } \\
(\mathbf{m g} / \mathbf{1 0 0} \mathrm{ml}) \\
(\mathrm{n}=22)\end{array}$ & $\begin{array}{c}\text { Platelet Aggregation } \\
\text { Time (min) } \\
(\mathbf{n}=27)\end{array}$ \\
\hline $\begin{array}{l}\text { Before starting } \\
1 \text { month } \\
2 \text { months } \\
3 \text { months } \\
6 \text { months }\end{array}$ & $\begin{array}{l}\text { Mean } \\
\text { Mean } \\
\mathbf{P} \\
\text { Mean } \\
\mathbf{P} \\
\text { Mean } \\
\mathbf{P} \\
\text { Mean } \\
\mathbf{P}\end{array}$ & $\begin{array}{c}12 \\
12.4 \\
0.05 \\
12.6 \\
0.05-0.02 \\
12.8 \\
0.01-0.001 \\
12.7 \\
0.02-0.01\end{array}$ & $\begin{array}{c}40 \cdot 6 \\
41 \cdot 4 \\
0.4-0 \cdot 3 \\
41 \cdot 6 \\
0 \cdot 2-0 \cdot 1 \\
42 \cdot 4 \\
0.05-0.02 \\
41 \cdot 3 \\
-\end{array}$ & $\begin{array}{c}12 \\
12 \cdot 6 \\
0 \cdot 1-0.05 \\
12 \cdot 9 \\
>0.001 \\
13 \\
>0 \cdot 001 \\
12.9 \\
0.02-0.01\end{array}$ & $\begin{array}{c}19.1 \\
19.5 \\
0.6 \\
20.9 \\
0.1-0.05 \\
21 \cdot 6 \\
0.01-0.001 \\
20 \cdot 1 \\
0.1-0.05\end{array}$ & $\begin{array}{c}250 \\
230 \\
0.01-0.001 \\
228 \\
0.05-0.02 \\
247 \\
0.2-0.1 \\
230 \\
0.5-0.4\end{array}$ & $\begin{array}{c}483 \\
525 \\
0.1-0.05 \\
514 \\
0.3-0.2 \\
569 \\
0.02-0.01 \\
595 \\
>0.001\end{array}$ \\
\hline
\end{tabular}

TABLE III-Results of Coagulation Studies up to Six Months in 13 Women who Changed from Chlormadinone Acetate to Norethisterone. Numbers of Women are given in Parentheses

\begin{tabular}{|c|c|c|c|c|c|c|c|}
\hline & & $\begin{array}{c}\text { Prothrombin } \\
\text { Time (sec) } \\
(\mathbf{n}=13)\end{array}$ & $\begin{array}{l}\text { Cephalin Time } \\
(\mathrm{sec}) \\
(\mathrm{n}=13)\end{array}$ & $\begin{array}{l}\text { Factor VII } \\
\text { Assay (sec) } \\
(\mathrm{n}=13)\end{array}$ & $\begin{array}{c}\text { Factor } \mathbf{X} \\
\text { Assay (sec) } \\
(\mathrm{n}=13)\end{array}$ & $\begin{array}{c}\text { Fibrinogen } \\
(\mathbf{m g} / \mathbf{1 0 0} \mathrm{ml}) \\
(\mathrm{n}=10)\end{array}$ & $\begin{array}{c}\text { Platelet Aggregation } \\
\text { Time (min) } \\
(n=12)\end{array}$ \\
\hline $\begin{array}{l}\text { Before starting } \\
1 \text { month } \\
2 \text { months } \\
3 \text { months } \\
6 \text { months }\end{array}$ & $\begin{array}{l}\text { Mean } \\
\text { Mean } \\
\mathbf{P} \\
\text { Mean } \\
\mathbf{P} \\
\text { Mean } \\
\mathbf{P} \\
\text { Mean } \\
\mathbf{P}\end{array}$ & $\begin{array}{c}12 \cdot 4 \\
12 \cdot 4 \\
12 \cdot 5 \\
0 \cdot 5 \\
12 \cdot 3 \\
0 \cdot 9-0 \cdot 8 \\
12 \cdot 5 \\
0.9-0 \cdot 8\end{array}$ & $\begin{array}{c}40.6 \\
40.4 \\
0.7-0.6 \\
40.5 \\
0.6-0.5 \\
39.5 \\
0.1-0.05 \\
38.5 \\
0.2-0.1\end{array}$ & $\begin{array}{c}12 \cdot 8 \\
12 \cdot 7 \\
0.8-0.7 \\
12 \cdot 7 \\
0.8-0.7 \\
12.5 \\
0.6-0.5 \\
12 \cdot 8 \\
0.9-0.8\end{array}$ & $\begin{array}{c}18 \cdot 8 \\
20 \\
0 \cdot 6-0 \cdot 5 \\
20 \cdot 7 \\
0 \cdot 3 \\
19 \cdot 8 \\
0 \cdot 5-0 \cdot 4 \\
21 \cdot 2 \\
0 \cdot 2-0 \cdot 1\end{array}$ & $\begin{array}{c}240 \\
289 \\
0.3-0.2 \\
274 \\
0.1-0.05 \\
251 \\
0.8-0.7 \\
226 \\
0.7-0.6\end{array}$ & $\begin{array}{c}523 \\
552 \\
0 \cdot 2-0 \cdot 1 \\
543 \\
0.8-0 \cdot 7 \\
544 \\
0 \cdot 5 \\
580 \\
0 \cdot 2-0.1\end{array}$ \\
\hline
\end{tabular}

TABLE IV-Results of Coagulation Studies up to Six Months in Six Women who were Started Postpartum on Norethisterone. Numbers of Women are given in Parentheses

\begin{tabular}{|c|c|c|c|c|c|c|c|}
\hline & & $\begin{array}{l}\text { Prothrombin } \\
\text { Time (sec) } \\
(\mathbf{n}=6)\end{array}$ & $\begin{array}{l}\text { Cephalin Time } \\
(\mathrm{sec}) \\
(\mathbf{n}=6)\end{array}$ & $\begin{array}{l}\text { Factor VII } \\
\text { Assay (sec) } \\
(\mathrm{n}=6)\end{array}$ & $\begin{array}{c}\text { Factor X } \\
\text { Assay (sec) } \\
(n=6)\end{array}$ & $\begin{array}{c}\text { Fibrinogen } \\
(\mathrm{mg} / 100 \mathrm{ml}) \\
(\mathrm{n}=6)\end{array}$ & $\begin{array}{c}\text { Platelet Aggregation } \\
\text { Time (min) } \\
(n=6)\end{array}$ \\
\hline $\begin{array}{l}\text { Before starting } \\
1 \text { month } \\
2 \text { months } \\
3 \text { months } \\
6 \text { months }\end{array}$ & $\begin{array}{l}\text { Mean } \\
\text { Mean } \\
\mathbf{P} \\
\text { Mean } \\
\mathbf{P} \\
\text { Mean } \\
\mathbf{P} \\
\text { Mean } \\
\mathbf{P}\end{array}$ & $\begin{array}{c}12 \cdot 2 \\
12 \cdot 3 \\
0.9-0.8 \\
12 \cdot 4 \\
0.4-0.3 \\
12 \cdot 4 \\
0.5-0.4 \\
12 \cdot 7 \\
0.5-0.4\end{array}$ & $\begin{array}{c}42 \\
43 \cdot 6 \\
0 \cdot 2-0 \cdot 1 \\
40 \cdot 7 \\
<0 \cdot 9 \\
41 \cdot 2 \\
0.5-0.4 \\
39 \cdot 8 \\
0.02-0.01\end{array}$ & $\begin{array}{c}12 \\
12 \cdot 3 \\
0 \cdot 5-0 \cdot 4 \\
12 \cdot 6 \\
0 \cdot 3-0 \cdot 2 \\
12 \cdot 4 \\
0 \cdot 2-0 \cdot 1 \\
12 \cdot 5 \\
0 \cdot 6-0 \cdot 5\end{array}$ & $\begin{array}{c}22 \cdot 4 \\
20 \\
0.1-0.05 \\
19 \cdot 4 \\
0 \cdot 1-0.05 \\
22 \cdot 8 \\
0.8-0.7 \\
23 \cdot 2 \\
0.4-0.3\end{array}$ & $\begin{array}{c}274 \\
233 \\
0.8-0 \cdot 7 \\
246 \\
0 \cdot 2-0 \cdot 1 \\
233 \\
0.05-0.02 \\
244 \\
0.3-0.2\end{array}$ & $\begin{array}{c}555 \\
596 \\
0 \cdot 3-0 \cdot 2 \\
551 \\
0.5-0.4 \\
545 \\
<0 \cdot 9 \\
633 \\
<0.9\end{array}$ \\
\hline
\end{tabular}


Blair, 1960). It is now well established that it is the oestrogens which appear to be responsible for the adverse effects on clotting and platelet function (Poller et al., 1971a, 1971b) and for the thrombotic tendency (Inman et al., 1970). The 19-norsteroid might in theory therefore have produced similar changes to oestrogen-containing oral contraceptives.

The lack of adverse effects on blood clotting with norethisterone is in contrast to our previous findings with all types of conventional combined oral contraceptives where significant rises of factors VII and $\mathrm{X}$ as well as other undesirable clotting changes occurred within the first three months of administration. In addition, we have found accelerated cephalin times and Chandler's tube platelet aggregation times with combined preparations. A number of authors have found a tendency to increased platelet adhesion (Ygge et al., 1969) with combined preparations. Von Kaulla and von Kaulla (1970) showed a fall in antithrombin III levels with conventional oral contraception. Several authors have also reported rises in fibrinogen levels with oestrogen-progestogen administration (Nilsson and Kullendar, 1967). The lack of such changes with six months' norethisterone administration is reassuring.

In a previous long-term follow-up of a group taking chlormadinone acetate no change in clotting tests was recorded but acceleration of the Chandler's tube platelet aggregation test was recorded after two years, although this was significantly less then a long-term group on combined ostrogen-progestogen preparations. Longer follow-up will therefore be required to be certain that delayed or cumulative effects do not occur at a later stage of the present study of norethisterone administration.

The absence of adverse effects on clotting and platelets in the group of women not previously having taken oral contraceptives was also supported by the absence of changes in women who changed to norethisterone from chlormadinone acetate and the small group of postpartum patients. None of the patients in this trial suffered from thrombosis but this was unlikely in view of the small size of the groups tested. The absence of clotting and platelet changes is not proof that oral contraception with 19-norsteroid progestogens will be devoid of thrombotic complications, but the evidence that these undesirable side effects on clotting have been avoided raises the possibility of a reduction in thromboembolic risk when they are used instead of combined preparations.

The work was performed while in receipt of a long-term grant from the Medical Research Council. Gratitude is expressed to Syntex Pharmaceuticals for supplies of norethisterone and a grant for technical help.

Lesley Eaton and Joy Holley provided additional technical help in this investigation.

\section{References}

Abilgaard, U., Graven, K., and Godal, H. C. (1970), Thrombosis et Diathesis Haemorrhagica, 24, 224.

Brown, J. B., and Blair, H. A. F. (1960). Proceedings of the Royal Society of Medicine, 53, 433.

Burslem, R. W., Gough, D., and Mandara, M. (1972). To be published. Hirsh, J., and McBride, J. A.' (1965). British Medical fournal, 2, 797.

Inman, W. H., Vessey, M. P., Westerholm, B., and Engelund, A. (1970) British Medical fournal, 2, 203.

Kaulla, E. von, and Kaulla K. N. von (1970). Lancet, 1, 36.

Leavelle, Dennis E., Mertins, B. F., Bowie, W. E. J., and Owen, C. A., jun (1971). American fournal of Clinical Pathology, 55, 452

Merskey, C., Lalezari, P., and Johnson, A. J. (1969). Proceedings of the Society for Experimental Biology and Medicine, 131, 871.

Nilsson, I. M., and Kullander, S. (1967). Acta Obstetricia et Gynecologica Scandinavica, 46, 286

Poller, L., Tabiowo, Anne, Thomson, Jean M. (1968). British Medical fournal, 3, 218.

Poller, L., Thomson, Jean M., Tabiowo, Anne, and Preist, Celia M. (1969). British Medical fournal, 1, 554.

Poller, L., Thomson, Jean M., Thomas, Wendy, and Wray, Carol (1971a). British Medical fournal, 1, 705.

Poller, L., Thomson, Jean M., and Thomas, Wendy (1971b). British Medical fournal, 4, 648 .

Poller, L., Thomson, Jean M., Sear, C. H. J., and Thomas, Wendy (1971c). Fournal of Clinical Pathology, 24, 626

Thomson, Jean M., and Poller, L. (1965). British Medical fournal, 2, 270

Ygge, J., Brody, S., Korsan Bengsten, K., and Nilsson, L. (1969). American fournal of Obstetrics and Gynecology, 104, 87.

\title{
Glucose Tolerance and Insulin Secretion in Patients with Chronic Duodenal Ulcer
}

\author{
C. S. HUMPHREY， J. R. W. DYKES， D. JOHNSTON
}

British Medical fournal, 1972, 4, 393-396

\section{Summary}

An oral glucose tolerance test has been used to compare carbohydrate metabolism in patients suffering from chronic duodenal ulceration with that in a matched group of normal subjects. A significantly greater rise in blood glucose concentration was observed in the duodenal ulcer group, and this was associated with a significantly greater output of insulin. The reason for these findings may be an abnormal secretion of one or more of the smallbowel hormones.

\section{Introduction}

Abnormal glucose tolerance curves have been described after both partial gastrectomy and vagotomy and drainage, and have been attributed in large part to abnormally rapid gastric empty-

University Departments of Surgery and Chemical Pathology, The General Infirmary, Leeds

C. S. HUMPHREY, M.B., CH.B., Research Assistant, Honorary Registrar J. R. W. DYKES, M.B., CH.B., Lecturer

D. JOHNSTON, M.B., F.R.C.S., Reader in Surgery ing (Evensen, 1942; Cameron et al., 1969; Holdsworth et al., 1969; Perreau et al., 1969). Less attention has been paid to the question of carbohydrate metabolism in the preoperative ulcer patient. Early studies yielded conflicting results, probably because the techniques of the glucose tolerance tests were not standardized and the methods used for estimating blood glucose concentrations were relatively crude. Furthermore, changes in plasma insulin levels could only be inferred from the observed variations in blood glucose concentration.

The importance of the gastrointestinal hormones in modifying the insulin response to ingested carbohydrate is established (McIntyre et al., 1964, 1965). The altered gastrointestinal physiology accompanying chronic peptic ulcer disease might be reflected in an abnormal pattern of carbohydrate metabolism. We have used an oral glucose tolerance test with measurement of blood glucose and plasma insulin concentrations to investigate a group of patients with chronic duodenal ulcer in an attempt to define any such abnormality.

\section{Patients and Methods}

Fifteen patients with a lengthy history of dyspepsia, in whom a radiological diagnosis of chronic duodenal ulcer had been 